\title{
NAS TRILHAS DO LOBO
}

\author{
LUÍS FERNANDo PRADO TELLES
}

[1] Blanco, María Luisa. Conversas com António Lobo Antunes. Lisboa: Publicações Dom Quixote, 2002, p. 125 .

[2] Eagleton, Terry. Marxismo e crítica literária. Trad. António de Souza Ribeiro. Porto: Edições Afrontamento, 1978 , pp. 36-37.

É consenso que as palavras de um autor sobre a sua própria obra não devem ser tomadas como diapasão único para o seu julgamento; no entanto, podem oferecer boas pistas para a formulação de estratégias de leitura. Em uma de suas muitas entrevistas, Lobo Antunes viuse diante de duas perguntas bastante complexas justamente porque simples e diretas. A certa altura, a entrevistadora perguntou: "E você, o que quer contar? Aonde quer chegar?”. Lobo Antunes, por sua vez, não se furtou às perguntas, assumindo a via da falsa modéstia, e respondeu, também diretamente: "O que pretendo é transformar a arte do romance, a história é o menos importante, é um veículo de que me sirvo, o importante é transformar essa arte, e há mil maneiras de fazêlo, mas cada um tem de encontrar a sua" interpretação irônica que poderia ser feita tanto das perguntas como da resposta, o caso é interessante, pois traz à baila questões antigas sobre o conteúdo e a forma da obra literária.

Quais são os temas de que trata Lobo Antunes em suas narrativas e de que modo os apresenta? Por mais assentada que seja a noção de que em literatura a forma gera o conteúdo e vice-versa, o que resulta numa certa indistinção entre ambos os termos, as perguntas sobre um ou sobre outro não deixam de surgir a partir de uma distinção que parece estabelecer-sea priori.Contudo, as respostas a essas perguntas acabam sempre apontando para uma impossibilidade de distinção. Em outros termos, esse paradoxo parece confirmar a idéia de Terry Eagleton quando considera que, apesar de a forma e o conteúdo serem inseparáveis na prática, ainda assim permanecem teoricamente distintos ${ }^{2}$. Em termos teóricos, então, o que a resposta de Lobo Antunes acentua é uma preocupação maior em relação à forma do que ao conteúdo. A história, ou "o que" se conta, estaria em segundo plano em relação ao "como" se conta. De certa maneira, o autor estaria em busca, como 
diz, da sua maneira de transformar a arte do romance. Talvez seja por isso que entende o conjunto de sua obra como um extenso caminho de autocorreção, de busca contínua pela sua forma particular capaz de modificar a arte do romance. Esta conclusão pode ser depreendida de uma outra declaração sua, em entrevista ainda anterior à acima citada, quando considera todos os livros como o resultado de um processo contínuo de reescrita de seu romance de estréia: "pelo menos para mim, cada livro serve para corrigir o anterior. No fundo, o que tenho escrito, livro a livro, é uma Memória de elefante sucessivamente corrigida"3. Seconsideradas em conjunto, estas duas declarações de Lobo Antunes querem dizer, em outros termos, que, além de importar-se menos com a "história" do que com a "arte" como é construída, esta "história", na verdade, seria sempre a mesma, mas repetida de modos distintos.

Ainda que seja possível identificar alguns temas recorrentes ao longo de toda a sua produção romanesca (tais como o da guerra colonial na África, o exercício da psiquiatria, a separação da esposa, a falta das filhas, a cidade de Lisboa, o bairro de Benfica, a revolução de 74, a ditadura salazarista, a direita reacionária, os movimentos comunistas, as grandes famílias burguesas decadentes etc.), seria malfadada a estratégia de leitura que levasse a sério o postulado da separação entre forma e conteúdo, procurando descobrir se, de fato, Lobo Antunes conta sempre a mesma história de modos diferentes, ou aquela que procurasse delimitar, a priori, genérica e abstratamente o que seria o romance ao qual se refere Lobo Antunes, buscando responder em que medida a obra do escritor conseguiria modificar a arte desse gênero. Isso, contudo, não impede que sua obra seja remetida ou identificada a uma ou outra tradição ficcional. O próprio autor mostra, em muitas de suas entrevistas, as fontes das quais se alimenta. Além dos sempre lembrados Tolstoi, Flaubert, Proust, Conrad e Tchekhov, Lobo Antunes dá destaque aos autores sul-americanos, em especial Júlio Cortázar,Juan Rulfo, Ernesto Sábato e Vargas Llosa.Sobre os norte-americanos, sempre afirma invejar a capacidade de concisão de Hemingway e a qualidade dos romances de William Faulkner de se reinventarem a cada leitura, tal como a poesia. Sobre O some a fúria diz tê-lo visitado já mais de trinta vezes 4 . Outra obra que declara tê-lo acompanhado ao longo de sua vida é Viagem ao fim da noites, do francês Louis-Ferdinand Céline; do qual parece ter cultivado o estilo da linguagem despudorada e contundente. Sobre os autores portugueses, reconhece a singularidade e a importância de Agustina Bessa-Luís e lembra sempre de ressaltar a qualidade das obras de Augusto Abelaira, Almeida Faria, Lídia Jorge, João de Melo e, com especial predileção, as de seu grande amigo José Cardoso Pires.

Vários são os caminhos tortuosos para os quais podem nos enviar as respostas do autor às perguntas referidas de início, algumas
[3] Entrevista concedida a Rodrigues da Silva. "Mais perto de Deus". Jornal de Letras, Artes e Ideias, 6/10/1999, pp. 5-8. In: Arnaut, Ana Paula. Entrevistas com António Lobo Antunes, 1979-2007: confissões do trapeiro. Lisboa: Almedina, 2008, pp.305-23.

[4] No texto de apresentação de uma tradução portuguesa desta obra (Faulkner, William. O som e a fúria. Lisboa: Publicações Dom Quixote, 1994), Lobo Antunes declarou o seguinte: "O som e a fúria possui a qualidade de ser um romance que, tal como a grande poesia, se relê no maravilhoso da descoberta: a todo o passo damos com pormenores que nos haviam passado despercebidos, em cada página nos emocionamos. Já visitei este livro mais de 30 vezes, e continuarei de certo a fazê-lo com o mesmo deslumbramento e o mesmo entusiasmo".

[5] Em entrevista concedida a Baptista-Bastos, Lobo Antunes declarou ter lido mais de vinte vezes esta obra de Céline (cf. "Escrever não me dá prazer". Jornal de Letras, Artes e Ideias, 19/11/1985, pp. 3-5. In: Arnaut, op. cit., p. 75). 
[6] Sobre esta divisão em ciclos, ver, por exemplo, a entrevista do autor a Rodrigues da Silva. Jornal de Letras, Artes e Ideias, 13/04/1994, pp. 16-19. In: Arnaut, op. cit., pp. 214-15.

[7] Cf. Entrevista concedida a António Tavares Teles. Record, 8/12/1996, pp. 7-10.In: Arnaut, op. cit., p. 260. pistas podem ser falsas. No entanto, há uma que pode ser mais interessante:essa pista levaria a uma leitura imanente, que tomaria como critério a própria obra de Lobo Antunes para se tentar entender sua proposta de modificação da arte do romance. Romance, neste caso, não seria tomado genericamente, mas como a narrativa construída por Lobo Antunes em cada uma de suas obras. Entender, portanto, como Lobo Antunes modifica a arte do romance significa antes entender como ele modifica a sua própria arte, a forma de narrar ao longo de suas obras, do que pensá-las em relação a uma ou outra tradição estabelecida idealmente.

O ponto a ser trabalhado, aqui,é a existência de um fenômeno que parece possuir uma natureza comum, mas que se impõe de modos distintos ao longo de sua obra. Este fenômeno consiste no fato de a narrativa de Lobo Antunes, em vários momentos eem diferentes níveis, verse diante da impossibilidade de se completar ou mesmo de se realizar. Contudo, o fato curioso é que ela encontrará solução de continuidade justamente no momento de sua incompletude ou irrealização. Nesse sentido, é possível falar num movimento concomitante, e paradoxal, de afirmação e negação: sua narrativa afirma-se no momento mesmo em que se nega. Trata-se, pois, de um movimento dialético que se manifesta de diferentes modos em seus romances.

Procuraremos restringir a presente análise ao que o próprio autor entendeu como os dois momentos iniciais. Lobo Antunes reconhece haver pelo menos quatro ciclos em sua obra. O primeiro considera ser o de sua aprendizagem como escritor e é composto pelos títulos:Memória de elefante (1979), Os cus de Judas (1979) e Conhecimento do inferno (1980). O segundo seria aquele em que o país se torna o personagem principal - ciclo das antiepopéias, como afirma.Aeste momento pertencem as quatro obras subseqüentes: Explicação dos pássaros (1981), Fado alexandrino (1983), Auto dos danados (1985) e As naus (1988). O terceiro ciclo seria uma mistura dos anteriores e é chamado pelo escritor de a "trilogia de Benfica", já que nos três romances desta fase retrata-se o bairro de Lisboa em que o escritor passou a sua infância; são eles: Tratado das paixões da alma (1990), A ordem natural das coisas (1992) e A morte de Carlos Gardel (1994)6. O quarto ciclo seria composto por aquilo que o autor denominou uma tetralogia, designada como sendo o ciclo do poder. Trata-se de "quatro histórias sobre o poder, as relações dentro do poder e, sobretudo, o poder visto pela direita reacionária"7. Os títulos que compreendem esse momento são $O$ manual dos inquisidores (1996), Oesplendor de Portugal (1997), Exortação aos crocodilos (1999) e Não entres tão depressa nessa noite escura (2000).

Depois dessa tetralogia, Lobo Antunes tem nos surpreendido ainda com mais seis belos e inovadores romances: Que farei quando tudo arde (2001), Boa tarde às coisas aqui em baixo (2003), Eu hei-de amar uma 
pedra (2004), Ontem não te vi em babilônia (2006), O meu nome é legião (2007) e O arquipélago da insônia (2008). Apesar de algumas de suas obras serem editadas no Brasil desde a década de 1980, como é o caso, por exemplo, de Oscus de Judas ${ }^{8}$, nunca houve a iniciativa por parte das editoras brasileiras de se proceder a uma edição mais sistemática de todo o conjunto da obra desse autor português. Os esforços nesse sentido intensificaram-se apenas ao final da década de 1990, com a publicação, pela editora Rocco, de quatro títulos, o segundo da "trilogia de Benfica" e os três iniciais da "tetralogia do poder". Mais recentemente, a editora Objetiva adquiriu os direitos de publicação no Brasil de toda a obra do escritor e tem oferecido ao leitor brasileiro a possibilidade não apenas de ver reeditados títulos mais antigos, mas também de conhecer alguns mais recentes, como Eu hei-de amar uma pedra e Ontem não te vi em babilônia, lançados, respectivamente, em 2007 e 2008 , sob o selo Alfaguara. Se a razão de as obras completas de Lobo Antunes não terem sido sistematicamente editadas aqui não está, em absoluto, na falta de interesse do leitor brasileiro, muito menos está num possível desinteresse do autor em relação ao Brasil. Lembremos que Lobo Antunes é neto de brasileiros: sua família veio "diretamente de Belém do Pará para Benfica" 9 . Em certa fase de sua carreira, quando andava desgostoso com Portugal, aventou a possibilidade de morar algum tempo no Brasilio ${ }^{\circ}$. Assim, apesar desse grau de parentesco do autor com o Brasile do largo interesse dos leitores brasileiros pelos seus romances, talvez falte a estes uma visão de conjunto da obra, muito em razão do próprio modo intermitente e esporádico como se deu o processo de publicação de seus títulos no país.

Os romances de sua trilogia inicial são ainda muito tributários, em termos de técnicas literárias, da narrativa psicológica do início do século XX, não vão muito além da fonte de que bebem, seja ainda em relação a Proust, ou mesmo no que se refere ao psicologismo ou à prosa de vanguarda de alguns romancistas portugueses do período. Nestas obras, o que podemos ver encenado é o paradoxo assinalado por Adorno ${ }^{11}$ a respeito do romance moderno que consiste na impossibilidade de narrar, apesar de não se poder deixar de narrar. Tal paradoxo, segundo Adorno, não teria levado o romance a deixar de narrar, mas a uma crise do narrador como figura impessoal, organizadora e totalizante. A causa dessa crise seria dada pelo encurtamento da perspectiva narrativa, que estaria, agora, restrita à da personagem, mais particularmente à sua mente.

Em Memória de elefante ${ }^{12}$, a figura do narrador faz-se presente e identificável por meio de uma enunciação narrativa que se refere ao protagonista, um médico psiquiatra. Pelas mãos desse narrador, acompanhamos um dia da vida desse personagem, desde sua manhã de trabalho no Hospital Miguel de Bombarda (em que o pró-
[8] Ver, por exemplo, a publicação deste romance pela editora Marco Zero, em 1984.

[9] Cf. Entrevista concedida a Clara Ferreira Alves. "Lobo Antunes: 'Fui bem comportado durante tempo de mais!'”. Jornal de Letras, Artes e Ideias, 22/11/1983, pp. 3-4. In: Arnaut, op. cit., p. 63 .

[10] Ibidem.p. 58 .

[11] Adorno, Theodor. W. "Posição do narrador no romance contemporâneo". In: Notas de literatura. Trad. Jorge de Almeida. São Paulo: Duas Cidades/Editora 34, 2003, pp. 55- 64 .

[12] Antunes, António Lobo.Memória de elefante. Lisboa: Publicações Dom Quixote, 1997 [1979]. 
[13] Gérard Genette faz uma diferenciação entre narrativa de eventos e a narrativa de falas. O primeiro tipo seria o responsável por instaurar a diegese, ou seja, por criar a história da qual dependem as categorias de espaço e tempo que configuram propriamente um enredo. Sob a designação de narrativa de falas, Genette considera tanto a representação do discurso pronunciado como o chamado discurso interior, seja um monólogo interior ou um fluxo de consciência (Genette, Gérard. Figures III. Paris: Éditions du Seuil, 1972, pp.183-203).

[14] Antunes. Os cus de Judas. Lisboa: Publicações Dom Quixote, 1994 [1979].

[15] Idem. Conhecimento do inferno. Rio de Janeiro: Objetiva/Alfaguara, 2006 [1980].

[16] Idem, Memória de elefante, op. cit., pp. 14-15.

[17] Estas imagens não são apenas recorrentes nestes romances iniciais, mas são referidas pelo autor também em entrevista, quando discorreu sobre a época em que praticava hóquei sobre patins pelo clube Benfica: "Começamos a patinar muito cedo, porque íamos para o Jardim Zoológico onde estava aquele senhor preto todos os domingos, havia aquelas meninas todas vestidas de branco, pareciam anjos, davam piruetas debaixo daquelas árvores..." (Entrevista a Francisco José Viegas. "Nunca li um livro meu". Ler: Revista do Círculo de Leitores, $\mathrm{n}^{\circ} 37,1997$, pp. 30-43. In: Arnaut, op. cit.,.p. 290). prio Lobo Antunes exerceu a sua profissão durante grande parte da vida), até a madrugada em seu apartamento. Apesar de o romance ser constituído quase que em sua totalidade por aquilo que a teoria da narrativa entende de modo mais genérico como sendo o récit de paroles (em especial o chamado récit de paroles intérieur) ${ }^{13}$, em contrapartida ainda se mostra estruturada pela voz de um narrador que é o responsável por introduzir o récit d'évènements capaz de instaurar uma diegese bastante clara e uma ordem temporal suficientemente linear. Em Os cus de Judas ${ }^{14}$, não havendo categoria do narrador em terceira pessoa para iniciar os capítulos por meio da marcação da mudança de espaço e de tempo, o recurso utilizado para marcar a progressão narrativa é o da simulação de uma interlocução, que teria como função delimitar os passos de uma conversa estabelecida entre o personagem narrador e a personagem feminina que lhe ouve. A utilização dessa técnica serve para emoldurar o discurso psicológico do narrador protagonista no interior de um quadro diegético espacial e temporalmente delimitado. Já no caso de Conhecimento do inferno ${ }^{15}$, os momentos narrativos são estruturados a partir da referência aos pontos de passagem (e de paragem) da viagem realizada pelo protagonista:Algarve, Albufeira, Messines, Aljustrel, Lisboa, entre outros lugares. Neste romance, volta-se à narrativa em terceira pessoa sob a perspectiva de primeira, contudo a indistinção das vozes no interior da narrativa é ainda mais explorada nesta obra.

A oscilação entre a narrativa em primeira e em terceira pessoa tanto no interior das obras, como entre elas, resulta na representação de dois lugares distintos de enunciação, mas que se sobrepõem de maneira a não se distinguirem. $O$ efeito primeiro disso poderia ser o da criação de um reforço do caráter confessional e autobiográfico da narrativa. Porém, a questão não se resolve aí, visto que o próprio caráter confessional é denunciado pela narrativa como ficção também. Daí resultam a dissolução da categoria totalizante do narrador e a denúncia de um outro espaço que estaria entre a categoria do narrador e do personagem - o da representação de uma autoconsciência ficcional.

As construções imagéticas utilizadas em Os cus de Judas para caracterizar as lembranças do protagonista são as mesmas dadas pelo narrador em terceira pessoa do primeiro romance, inclusive, quanto à escolha lexical. Em Memória de elefante, as contorcionistas do circo ao qual o protagonista leva suas filhas são detentoras de uma beleza “impalpável comum aos hálitos de gaze que anunciam nos aeroportos a partida dos aviões e às meninas de saias de folhos e botas brancas a desenharem elipses às arrecuas no rinque de patinagem do jardim zoológico"1 ${ }^{16}$. Em Os cus de Judas, vemos as mesmas imagens ${ }^{17}$ sendo evocadas logo ao início da narrativa. Assim diz o narrador protago- 
nista: "do que eu gostava mais no Jardim Zoológico era do rinque de patinação" com "as meninas de saias curtas e botas brancas, que, se falassem, possuíam seguramente vozes tão de gaze como as que nos aeroportos anunciam a partida dos aviões" ${ }^{18}$. Outro exemplo de coincidência nos modos de construção da subjetividade e de simulação da memória entre os personagens dos livros pode ser retirado do terceiro capítulo de Memória de elefante. A semelhança, aqui, é em relação ao modo como é referido o nascimento da filha: "Como sempre que se recordava de Angola um roldão de lembranças em desordem subiu-lhe das tripas à cabeça na veemência das lágrimas contidas: o nascimento da filha mais velha silabado pelo rádio para o destacamento onde se achava, primeira maçãzinha de oiro do seu esperma [...]"19.

A imagem usada para a caracterização da filha, assim como a descrição de como recebera a notícia de seu nascimento são muito próximas em Os cus de Judas, havendo, inclusive, coincidência de termos: "E agora, a dez mil quilômetros de mim, a minha filha, maçã do meu esperma [...], trazida pela cegonha da vozinha nítida do furriel de Gago Coutinho, explicando, alfa, bravo, rômio, alfa, charlie, ômega, o abraço do batalhão" 20 . Assim, de início, somos levados a concluir que, se neste segundo romance tanto os elementos discursivos da voz narrativa como os supostos referentes desses elementos são exatamente os mesmos daqueles apresentados pela voz narrativa do primeiro romance, então, os narradores seriam os mesmos. Contudo, esse raciocínio não pode ser confirmado se levarmos em consideração a caracterização da pessoa narrativa. Na primeira obra, o modo narrativo é o de uma terceira voz, que conta a história do protagonista, ao qual se refere o conteúdo da narrativa. Na segunda, o modo narrativo é constituído pela voz em primeira pessoa que também é responsável pelo seu conteúdo, já que narra fatos e pensamentos de sua vida. Se na primeira obra, portanto, há uma cisão entre modo e conteúdo, e na segunda há uma sobreposição entre esses dois elementos, apesar de ambos serem equivalentes nas duas obras, qual seria o diagnóstico possível desta problemática? Talvez a criação de um efeito de ficcionalização quando olhamos retrospectivamente as obras. A primeira poderia ser encarada como uma ficcionalização da vida do protagonista do segundo romance. Assim, o "eu" referente da primeira obra seria o "eu" narrador da segunda, e, portanto, a "realidade" referente da primeira seria o "eu" da segunda, que teria se cindido em dois no primeiro romance, em personagem e narrador.

Se apostarmos na hipótese de que o segundo romance funciona de modo a denunciar a ficcionalização da voz narrativa do primeiro, logo deveríamos aceitar, então, que o personagem protagonista de um seria o mesmo do outro e que o narrador do primeiro seria uma criação, uma estratégia narrativa, tanto do primeiro personagem
[18] Antunes, Os cus de Judas, op. cit., p. 7 .

[19] Idem, Memória de elefante, op. cit., p. 42.

[20]Idem, Os cus de Judas, op. cit., p. 61. 
[21] Idem, Conhecimento do inferno, op. cit., p. 61.

[22] Ibidem, p. 48 . como do segundo. Trata-se, aqui, da denúncia irônica da ficção que se estende para fora das obras, quando uma passa a iluminar o olhar sobre a outra e vice-versa.

Esta denúncia do ficcional que se opera pela relação entre esses dois romances iniciais é salientada em $O$ conhecimento do inferno. Neste terceiro título que fecha a trilogia, o autor identifica-se como personagem (na cena em que o amigo Zé Manuel apresenta o escritor Luiz Pacheco ao protagonista: “-Esteé o António Lobo Antunes - disse o Zé Manuel na sua voz afectuosa e doce que transformava as palavras em ternos bichos de feltro" ${ }^{21}$ ) e, inclusive, num dos momentos de sua viagem o protagonista é referido como sendo o autor do primeiro título: "Cruzou uma ou duas aldeias com nomes estranhos [...] elembrouse da casa sem água nem electricidade perto da Lagoa, a casa da Bia Grade,[...] onde, no Verão anterior, passara três semanas com a Isabel para acabar a Memória de Elefante [...]"22.

Em Conhecimento do inferno, a ficção transforma-se no seu referente real.Aqui, Lobo Antunes não apenas aponta para a sua máscara como dedo, mas nos faz ver que se quisermos enxergá-lo devemos não olhar por detrás da máscara, mas para a própria máscara. A leitura conjunta desses três títulos iniciais permite verificarmos um movimento dialético de afirmação da figura totalizante do narrador em terceira pessoa e de negação em nome de uma autonomia da voz em primeira que promove o apagamento da voz em terceira. Essa oscilação apontaria para um movimento duplo de aproximação e distinção entre as vozes do personagem e do narrador, o que resultaria um movimento de denúncia do ficcional que, em última instância, criaria a figura do autor manipulador dessas duas vozes. Contudo, esse mesmo autor, quando chamado para dentro da ficção para ser identificado à pessoa do personagem e ser referido pela voz narrativa em terceira pessoa, também passa a funcionar duplamente como afirmação e negação, visto que o autor das obras não deixa de ser também apenas uma criação delas. Trata-se, pois, da encenação de um jogo dialético de representação de uma subjetividade que se constrói a partir de uma indistinção promovida pelo deslizamento entre as categorias de personagem, narrador e autor; deste jogo não se pode extrair a exclusão ou a afirmação de uma ou outra categoria, mas afirmação e negação concomitantemente.

Os romances que compõem essa trilogia são considerados por Lobo Antunes como os mais autobiográficos. Em todos os três, há a crítica irônica à medicina, principalmente à psiquiatria; há a presença constante das evocações das lembranças da esposa, de quem se separou em 1976, bem como das filhas; mas, acima de tudo, é a experiência da guerra colonial em Angola que dá o tom do sofrimento dos discursos das vozes que conduzem as narrativas. De certa maneira, quando Lobo Antunes traz para a ficção a sua experiência, 
principalmente a da guerra colonial, é como se estivesse tentando livrar a possibilidade de essa experiência ser esquecida, ou mesmo de ser tomada como irreal. Ou melhor, ao fazer isso, Lobo Antunes acaba reservando à guerra o seu lugar no mundo real, o lugar de existência fora da ficção. Isso é o que parece confirmar o comentário do autor quando questionado em relação à sua insistência em relação ao tema da guerra colonial em seus romances:

Independentemente do valor que a nossa geração, literariamente, possa vir a ter ou não ter, eu penso que ela é uma geração diferente das outras, porque é uma geração marcada pela guerra colonial. [...] Penso que, apesar de tudo, se continua a tentarfalar, como se a guerra não tivesse existido, como se o Tarrafal e a Pide e tudo isso, nada tivesse existido23.

O que os três romances de estréia de Lobo Antunes mostram, por meio desse deslizamento entre as categorias de personagem, narrador e autor, é, principalmente, a dolorosa experiência da aprendizagem do regresso da guerra, "a sensação de despaisado que as pessoas que voltam da guerra têm", a sensação de "não pertencerem nem cá nem lá, de se terem perdido naquele lugare de não terem ainda conquistado lugar nenhum" 24. Pela sua "memória de elefante", Lobo Antunes oferecenos, assim, o "conhecimento do inferno", que é sentir-se nem cá nem lá, ou seja, que é a sensação de estar "nos cus de Judas".

Neste primeiro momento, o autor procura representar, essencialmente, o caráter ilimitado e imprevisível das relações ou associações imagéticas originárias de um pulsar da memória que não pode ser controlado, ou pré-programado, pelo próprio detentor do discurso. Tratase, portanto, de uma memória que se mostra, ou se evidencia, pelo seu transbordamento. No que se refere a esse aspecto, vale a transcrição de um trecho deMemória de elefante, em que testemunhamos o sofrimento do protagonista em relação à separação de sua mulher:

Amo-te tanto que te não sei amar, amo tanto o teu corpo e o que em ti não é o teu corpo que não compreendo porque nos perdemos se a cada passo te encontro, se sempre ao beijar-te beijei mais do que a carne de que és feita, se o nosso casamento definhou de mocidade como outros de velhice, se depois de ti a minha solidão incha do teu cheiro, do entusiasmo dos teus projectose do redondo das tuas nádegas, se sufoco da ternura de que não consigo falar, aqui neste momento, amor, me despeço e te chamo sabendo que não virás e desejando que venhas do mesmo modo que, como diz Molero, um cego espera os olhos que encomendou pelo correio 25 .

O curioso dessa passagem, que se pretende constituir como fruto do fluxo de pensamento do personagem, é o seu forte traço poético-
[23] Entrevista concedida a Rodrigues da Silva. "António Lobo Antunes ('Memória de Elefante') citando Blaise Cendrars: 'Todos os livros do mundo não valem uma noite de amor"'. Diário Popular, Suplemento Letras-Artes, 25/10/1979, pp. V-VI, IX. In: Arnaut, op. cit., pp. 25-26.

[24] Ibidem.p. 26.

[25] Antunes,Memória de elefante, op. cit., p. 44 . 
lírico, no sentido do trabalho evidente com a sonoridade das palavras, bem como com o ritmo das frases, as quais podem ser lidas, de forma cadenciada, como versos de um poema. Se considerarmos, a título de exemplo, apenas as quatro primeiras orações sintáticas que compõem a primeira linha do trecho citado, veremos que elas podem ser escandidas como versos, apresentando um número crescente de sílabas poéticas (há uma predominância no trecho todo do ritmo das redondilhas maiores e menores), o que representa um ritmo inversamente proporcional ao número de sílabas e que desencadeará na conclusão da quinta oração ("que não compreendo"), com um número de sílabas novamente reduzido em relação ao que iniciou o texto. Não se trata, portanto, de uma simples representação desordenada do pensamento do personagem operada pelo narrador, mas sim de um trabalho criador relativo à linguagem. No trecho citado, o descontrole em relação à memória converte-se, paradoxalmente, num excesso de controle do labor literário evidenciado por um discurso poético-lírico.Esse desencadear de metáforas conduziria a narrativa, curiosamente, não a um reforço de um sentido totalizante, mas a uma percepção fragmentária. Assim, apesar de a narrativa de Memória de elefante, bem como as das outras duas obras iniciais, reforçar a idéia de uma forte representação da subjetividade por meio de discursos narrativos modalizados metaforicamente, este mesmo processo conduz a uma fragmentação que, ao mesmo tempo em que representa uma interrupção no contínuo da narrativa, enviesando-a, também garante sua continuidade.

Em suas obras posteriores, esse processo de fragmentação será reforçado, mas numa outra direção:em vez da oscilação entre vozes narrativas de protagonista enarrador, haveráo total apagamento da figura do narrador(seja eleem terceira ou em primeira pessoa) e uma atenuação da força discursiva baseada na modalização metafórica responsável pela criação de excessos de sentidos. Em outros termos, as associações imagéticas e as metáforas serão progressivamente menos conduzidas por uma voz narrativa, ou seja, deixarão de se configurar como a expressão da marca de subjetividade do narrador ou de um personagem específico; em lugar disso, o trabalho de associação imagética e de criação de possíveis metáforas serálançado ao processo configurativo de leitura. Aliás, o desejo em diminuir o uso de associações imagéticas e metafóricas, visível em obras posteriores do autor, de certa maneira pode ser antevisto numa crítica feita pelo protagonista de Memória de elefante ao modo de construção da narrativa. Umaespécie de pedido de descul pas operado pela própria narrativa, por meio da voz desse personagem:

[...] porque é que só sei dizer que gosto através dos rodriguinhos de perífrases e metáforas e imagens, da preocupação de alindar, de pôrfranjas de crochet nos sentimentos, de verter a exaltação e a angústia na cadência 
pindérica do fado menor [...] depor palavras aos pés de uma escultura equivale às flores inúteis que se entregam aos mortos ou à dança da chuva em torno de um poço cheio: chiça para mim e para o romantismo meloso que me corre nas veias, minha eterna dificuldade em proferir palavras secas e exactas como pedras ${ }^{26}$.

Mas, na verdade, trata-se de um falso pedido de desculpas, tendo em vista a ironia subjacente ao discurso do personagem, uma vez que este é construído de acordo com o mesmo estilo que é nele criticado. É interessante notar que o comentário desse personagem aproxima-se bastante de um comentário que o próprio autor proferiu sobre o desejo de como gostaria de escrever: "Só quero que a minha escrita seja eficaz no sentido em que dizia Tolstoi para quem um bom escritor era aquele que não sacrificava a implacabilidade do seu relato à tentação de uma pirueta, de uma metáfora ou de um adjetivo" 27 . O discurso do personagem, de certa forma, não apenas parece coincidir perfeitamente com estas palavras do autor, mas tem um tom profético, já que adianta o rumo para o qual apontarão as narrativas posteriores de António Lobo Antunes.

Apesar de esse processo de enxugamento da linguagem ser realizado mais propriamente em obras recentes do autor, pode-se vislumbrar o início desta mudança no segundo momento do conjunto de suas obras. Ali, Lobo Antunes parece ensaiar alguns caminhos de reestruturação da narrativa, entre os quais um se tornará predominante, considerando as obras posteriores. Curiosamente, em mais de uma entrevista, o autor afirmou que deveria ter esperado para iniciar a publicação de suas obras a partir desse segundo ciclo ${ }^{28}$.

Nas duas primeiras obras desse momento, a voz do narrador funciona apenas como recurso secundário; cada vez mais a narrativa estará sujeita a uma multiplicidade de vozes. Em Explicação dos pássaros ${ }^{29}$, os capítulos correspondem aos dias de um final de semana, que se estende de uma quinta-feira a um domingo. Não se trata, contudo, de um final de semana qualquer, mas sim daquele em que o protagonista da história se suicida, personagem este só tardiamente identificado como o "assistente universitário" Rui S. Apesar de a narrativa ser aparentemente moldada por um tempo diegético bastante definido, este limite é problematizado pela própria narrativa que o instaura; assim, fica difícil recorrermos a uma sumarização mais definitiva conforme era possível fazer com as obras anteriores.

O problema é que esse narrador em terceira pessoa não oferece dados exteriores à mente do personagem protagonista que possam referendar a criação de uma ilusão realista, e que possam ser oferecidos ao leitor como contraprova. Reféns da mente do personagem, nós,
[26] Ibidem, pp. 124-125.

[27] Blanco, op.cit., p. 66

[28] Sobre o primeiro ciclo disse o autor certa vez: "O Memória de elefante é, claramente, um livro de aprendiz, Os cus de Judas é um livro binário, com aquele jogo entre mulher-guerra... E, depois, Conhecimento do inferno, que é provavelmente o mais fraco de todos, é onde começam a aparecer, ainda que timidamente, todos os processos que eu depois comecei a tentar desenvolver melhor nos livros a seguir. Mas, se eu voltasse atrás, teria começado a publicar com Explicação dos pássaros" (Entrevista a Francisco José Viegas, op. cit., pp. 30-43. In: Arnaut, op. cit., 282).

[29] Antunes. Explicação dos pássaros. Lisboa: Publicações Dom Quixote, 1997 [1981]. 
leitores, não podemos decidir se os fatos que vêm à tona são realmente vividos pelo personagem ou se são frutos da sua imaginação. Assim, tanto a variação de vozes como a introdução de outros tipos de textos no interior da narrativa (por exemplo, os depoimentos policiais, a homenagem póstuma publicada na revista de letras) permitem uma dupla interpretação. $\mathrm{O}$ suicídio pode ter ocorrido ou pode ter sido apenas uma criação da mente do personagem. Não se tratando de um "defunto-autor", Lobo Antunes optou por um narrador em terceira pessoa, mas delimitado pela primeira.

Qualquer decisão afirmativa, por um lado ou por outro, atende, acreditamos, ao paradigma do realismo. Seja um realismo que confia no estatuto do narrador como aquele capaz de referendar a ilusão de verdade dos fatos sobre o personagem, seja um realismo que aposta na supremacia do domínio do discurso interior do personagem, em que tudo seria reduzido à imaginação, às suas elucubrações. A nossa hipótese, contudo, é a de que desse jogo dúbio entre narrador e personagem há a intenção de se questionar o problema da própria criação literária, que acreditamos estar no cerne da discussão da obra de Lobo Antunes. O que se pretende representar não é nem o suicídio do personagem como um fato, nem a sua imaginação, mas a ficção que se auto-indica como ficção: a literatura que aponta para si própria. O suicídio, portanto, existe como uma categoria simbólica ou uma alegoria.

Se considerarmos o suicídio um fato criado pelo personagem-autor, então poderíamos dizer que o próprio suicídio é falho, do mesmo modo como a vida do personagem é falha, como a sua escrita é falha, a sua narrativa é falha, o seu romance é falho. Assim sugere o personagem Carlos, marido da irmã do protagonista, numa fala que se configura como a voz de alguém que comenta um espetáculo:

E por falar em suicídio, senhores e senhoras, e referindo-me especificamente ao número que o meu cunhado neste momento executa - a minha aposta é a de que falhará sem honra nem glória, a sua proeza, ou, antes, o seu projecto de proeza, do mesmo modo que até agora tem, por assim dizer, falhado tudo na vidaso.

Neste romance, há uma maior encenação de vozes que se apresentam mais independentes tanto do narrador em terceira pessoa como do protagonista. Há, por assim dizer, autonomia de cada uma das várias vozes que compõem a narrativa e que contribuem para sua maior fragmentação e para a constituição de um seu caráter cênico. As diferentes vozes do romance funcionam como as do coro da tragédia, que adiantam o fim ao qual está fadado o personagem principal. Se não é possível a formulação da hipótese de um defunto- 
autor, então Explicação dos pássaros consiste num blefe do qual é, ao mesmo tempo, autor e vítima.

O romance confirma dois caminhos cujos indícios já estavam traçados nas três obras iniciais de Lobo Antunes. O primeiro é o da dissolução da categoria do narrador como voz onipotente e detentora da totalidade narrativa. O segundo, decorrente do primeiro, constitui-se no fato de a narrativa desviar-se cada vez mais do paradigma de verdade baseado na ilusão realista, apontando para o seu caráter simbólico ou alegórico. Contudo, vale destacar que esse tal caráter não indica uma determinação de sentido, mas, ao contrário, leva à sua abertura ou indeterminação.

Em seu quinto romance, Fado alexandrino ${ }^{31}$, a narrativa é plurivocal. Contudo, as vozes dependem muito ainda de certo artifício narrativo que o autor já utilizara em Os cus de Judas, que diz respeito à estratégia da indicação de uma interlocução marcada sempre por um vocativo. As diversas vozes impõem-se como vozes de personagens que participam de uma conversa eque se dirigem sempre a um mesmo personagem que os ouve passivamente, sem responder ou dar continuidade ao diálogo. Por esta estratégia, criam-se, então, vários monólogos. Poderíamos dizer que o tempo da diegese corresponde ao de uma noite, e a ação se passa em três espaços:um restaurante, primeiro momento; uma boate, segundo; a casa de um dos personagens, terceiro. A conversa entre os personagens nesses três espaços ao longo da noite constitui o foco principal da história. Trata-se de ex-combatentes do mesmo batalhão que serviram na guerra colonial: o soldado Abílio, o alferes Jorge, o tenente-coronel Artur Esteves, o oficial das transmissões, um comandante e um capitão. As falas, em geral, sempre demarcadas, introduzidas ou interrompidas pelo vocativo "meu capitão" são dirigidas a ele, que está presente, mas não intervém na conversa. . O livro é dividido em três partes, intituladas "Antes da Revolução", "Revolução" e "Depois da Revolução". Cada uma delas contém doze capítulos e cada capítulo apresenta a voz de um dos personagens, que assume o primeiro plano da narrativa. Essa composição tão bem delineada em doze capítulos com a mesma extensão parece refletir o próprio título da obra, Fado alexandrino, gênero musical português composto, neste caso, porversos de doze sílabas. Como todo fado, este canta um destino trágico: o romance pode ser lido como um "fado" sobre a história de Portugal, do destino de Portugal.é uma crítica irônica à história recente desse país, pois nenhum período é visto de maneira positiva, seja ele anterior ou posterior à revolução de 25 de Abril de 1974. Os personagens são compostos a partir de uma visão crítica da moral burguesa: os militares contam suas histórias de contradição e incoerências. Ao mesmo tempo em que se mostram lutando pela permanência dos valores burgueses, são estupradores de crianças, gigolôs, corruptos, infiéis e assassinos frios.
[31] Idem. Fado alexandrino. Lisboa: Publicações Dom Quixote, 1987 [1983]. 
[32] Idem. Auto dos danados. Lisboa: Publicações Dom Quixote, 1987 [1985].
Talvez o viés mais característico dessa quinta obra de Lobo Antunes seja mesmo a ambivalência dos personagens, que se apresentam continuamente como vítimas até mesmo quando são configurados como os mais cruéis e terríveis dos vilões. Talvez esteja aí o sentido do "fado" que rege os destinos desses personagens ao longo de narrativas que se entrecruzam; ao fim e ao cabo, todos se mostram, tal como na obra posterior de Lobo Antunes, em estado de decadência moral, danação. Em Auto dos danados ${ }^{32}$, por sua vez, não há uma voz narrativa que funcione de modo a agenciar as demais vozes, nem se utiliza o recurso da simulação da interlocução como ocorre em Fado alexandrino. Com isso, os títulos das seções funcionam como índices tênues para orientar o processo configurativo de leitura à procura de um fio de ligação entre as narrativas. O título da primeira seção "Antevéspera da festa: Nuno todo o dia" - éum bom exemplo nesse sentido, pois faz referência direta a três aspectos narrativos importantes: um tempo, um fato e um personagem. Assim, ao iniciarmos a leitura de Auto dos danados supomos estarmos distantes dois dias do fato que fora anunciado como principal: a festa. Mas de que festa se trata? Nada sabemos de início.

Para quem parte da experiência de leitura dos títulos anteriores, Auto dos danados pode parecer um retorno ao modo narrativo das primeiras obras, principalmente pelo fato de a primeira parte ser configurada a partir de uma narrativa em primeira pessoa que conta um dia da vida de um personagem. Se antes, em Memória de elefante, seguimos os passos do psiquiatra, agora acompanhamos Nuno, um dentista, trabalhando em seu consultório no período da manhã, visitando a amante Mafalda e, depois, a casa dos pais durante a tarde e, à noite, em vez da viagem do Algarve a Lisboa, como em Conhecimento do inferno, Nuno viaja para o Alentejo, por causa da morte iminente do avô de Ana, sua esposa, que o acompanha nesta viagem, juntamente com o irmão de dez anos, Francisco. Em vez da festa, indicada no título dessa primeira parte do livro, o que se anuncia é a premente morte do patriarca latifundiário avô de Ana, Diogo. Fica, portanto, subentendida, desde o início, a referência irônica à morte deste personagem em contraponto à festa anunciada no título. Os três períodos do dia de Nuno correspondem aos três capítulos dessa primeira parte de Auto dos danados. Apesar de apontar para vários elementos das narrativas que completarão o restante do livro, a voz de Nuno desaparece, sendo referido apenas de passagem num ou noutro momento.

A segunda parte, intitulada "Véspera da festa: Ana à noite", é composta por duas seções designadas respectivamente Lado A e Lado B. Curiosamente, a primeira seção é narrada por Lurdes, mãe de Ana, o que não fica claro numa primeira leitura; a segunda seção está por conta da voz de Ana. Essas duas personagens funcionam como lados 
opostos de uma mesma história, de uma história indissociável. A seção subseqüente, "Primeiro dia da festa", é seguida por uma dedicatória: "À Lídia, onde quer que se encontre". A voz narrativa agora é a do irmão mais velho de Ana, viciado em heroína. A outra seção "Segundo dia da festa", refere-se ao dia da "véspera da minha morte", uma vez que a voz narrativa passa a ser a do moribundo Diogo.

A última seção do romance refere-se ao "Terceiro dia da festa", título que aparece explicado pela seguinte subscrição: "A importância da máquina de influenciar na gênese da esquizofrenia". Esta seção é composta por capítulos sem numeração e sem nome, em que as vozes narrativas se alternam também para relatarem o dia da morte daquele que detinha o poder sobre as posses da família, bem como para apresentarem as intrigas e trapaças concernentes às disputas familiares relativas à herança. $O$ período da festa pode estar relacionado, num primeiro plano, com os dias de uma tradicional tourada que ocorria na região em que a família se reunia às voltas do moribundo. Contudo, metafórica e ironicamente, a festa pode ser pensada como sendo a própria reunião familiar para comemorar a morte do patriarca. Mas a comemoração é frustrada quando o notário, depois de transferir os bens do patriarca ao parente que confabulara para tanto, revela que os únicos "bens" constituintes da referida herança eram dívidas.

O interessante do modo como é construído Auto dos danados é que os fatos narrados vão se estabelecendo a partir de um entrecruzamento das vozes dos personagens. Assim, nós, leitores, somos obrigados não apenas a reatualizar os dados de uma narrativa, projetando-os a uma outra que se apresenta na seqüência, mas também a retornar a narrativas anteriores de modo a preencher as lacunas que se apresentam à medida que progredimos na leitura. Nesse sentido, o processo configurativo de leitura de Auto dos danados não se faz numa via de mão única; ao contrário, muitas vezes a narrativa só é elucidada quando retornamos, regredimos. Não é possível chegar ao fim do romance com a sensação de completude, seja da história específica de um personagem, seja da narrativa geral. Assim, se de um lado essa fragmentação impulsiona o leitor a criar uma organização, de outro, não permite que ela realmente se complete em sua totalidade. Ou seja, o leitor é induzido a buscar uma totalização, mas, ao mesmo tempo, não lhe é permitido alcançá-la.

No romance seguinte desse segundo ciclo da obra de Lobo Antunes, $A s$ naus $^{33}$, a convocação do leitor irá também se impor como decisiva. No entanto, ele será cobrado num outro aspecto, a saber, o repertório de referências relativas à cultura portuguesa, principalmente no que se refere às personagens históricas e literárias. Entre as obras do autor, esta é a que melhor responde aos clichês teóricos comumente referidos a uma literatura dita pós-moderna, tais como os que se
[33] Idem. As naus. Lisboa: Publicações Dom Quixote, 1988. Este livro chamava-se, em princípio, $O$ regresso dascaravelas. O título não foi utilizado por razões de direitos autorais, pois já havia sido registrado por um escritor chamado Vitorio Kali (cf. Entrevista concedida a Luís Almeida Martins. "António Lobo Antunes: quis escrever um romance policial". Jornal de Letras, Artes e Ideias, 27/10/1992, pp. 8-11. In: Arnaut, op. cit., p. 163. 
[34] Seixo, Maria Alzira. Os romances de António Lobo Antunes. Lisboa: Publicações Dom Quixote, 2002, p. 172.

[35] Certa vez, perguntado sobre a constante presença do ódio em seus romances, principalmente em Auto dos danados, Lobo Antunes justificouse dizendo que seus romances "parecem filhos de Faulkner" (Entrevista a Clara Ferreira Alves, op. cit., pp. 31-33. In:Arnaut, op. cit., p. 91). alinham às noções de "paródia" e de "metaficção historiográfica". As naus é uma obra sui generis, visto que aposta num caminho diferente de todos os romances anteriores, e que também não será retomado de maneira explícita posteriormente. Nesta obra, o que predomina é o fantástico. Na verdade, este traço passa a ser constitutivo da própria obra como um todo, não havendo mais nela qualquer preocupação no que se refere à instauração de uma ordem ou estrutura diegética, ou ainda à utilização de estratégias narrativas tais como a da simulação da interlocução, como ocorre em Fado alexandrino, ou a fragmentação da perspectiva narrativa em Auto dos danados. Na verdade, em As naus, o problema do narrador (do estabelecimento da voz e da perspectiva narrativas) deixa de ser decisivo, visto que o seu caráter simbólico e até alegórico extrapola os limites impostos por tais categorias.

Neste romance, cria-se uma zona de indeterminação, pela qual tanto a história da colonização ilumina ironicamente a história da descolonização, como a história da descolonização revela uma terceira, intrinsecamente ambígua. Nela, a história do retorno dos colonizados a Portugal mostra o fracasso das promessas grandiloqüentes da expansão ultramarina; e estas, por sua vez, apontam, já num passado, certa decadência do Portugal contemporâneo.A principal estratégia de sobreposição de imagens é a da caracterização dos personagens africanos, sobretudo dos angolanos que chegam a Portugal fugidos da guerra colonial. No romance eles possuem nomes de grandes personalidades históricas, tal como Pedro Álvares Cabral, Luís de Camões, Vasco da Gama, Diogo Cão, Francisco Xavier, Manoel de Sousa Sepúlveda, Nuno Álvares Pereira, D. Sebastião, entre outras, ou, ainda, Cervantes, representando, metonimicamente, a Espanha. Esse tipo de tratamento ambíguo dado às figuras histórico-literárias caracteriza-se como aquilo que Alzira Seixo denominou de "per-versão"34 — característica básica e norteadora da narrativa, que não só apresenta uma nova versão da história e dos mitos portugueses, mas também lhes dá um sentido outro que funciona como o seu contrário.

Contudo, dos caminhos trilhados por Lobo Antunes em seu segundo ciclo de obras, o romance As naus não representa aquele que posteriormente foi seguido. Auto dos danados, cuja fonte mais evidente na tradição literária parece ser mesmo Faulkner35, é o que figura como modelo a ser retomado e desenvolvido nos romances que compõem a "trilogia de Benfica" e a "tetralogia do poder". Nestes, a dialética da narrativa mostra-se acentuada pelo processo cada vez mais explorado de multiplicação de vozes e perspectivas e por uma fragmentação mais evidente do discurso narrativo, inclusive no que se refere à própria distribuição das palavras na página. Em sua décima quarta obra, Não entres tão depressa nessa noite escura, a última obra da chamada "tetralogia do poder", Lobo Antunes dará outra guinada no caminho 
de reescrita de seu romance inicial; guinada esta que será decisiva no rumo de seu último ciclo de obras. Esta, em particular, ocupa um lugar único, pois representa o ponto máximo da dialética aqui estudada. Em se considerando a análise das formas da obra de Lobo Antunes em sua seqüência cronológica, poderíamos entendê-la como o momento em que se opera o reconhecimento daquilo que é revelado aos poucos nesta análise, que é construído ao longo do conjunto da obra, mas que somente agora se mostra plenamente: a encenação da dissolução do narrador como categoria totalizante. O reconhecimento traduz-se, portanto, pela percepção de que não é mais possível voltar a narrar a partir da perspectiva totalizante de um narrador. Mas como isso se dá neste romance? Justamente pela simulação de um retorno, criando a única volta possível que seria a de representar um narrador que não consegue completar a narrativa, levando ao paroxismo um fenômeno recorrente nas obras anteriores, qual seja, o de inserir o problema da construção ficcional dentro da própria ficção.

Em Não entres tão depressa nessa noite escura, todas as vozes parecem novamente filtradas por uma única voz, de Maria Clara, narradora que se apresenta na primeira parte. Contudo, essa voz que se desdobra nas demais não se impõe como dominante no sentido de controlar os caminhos narrativos ou de organizá-los de um modo verossímil ou coerente. Essa voz que se evidencia não se estabelece como uma categoria totalizante, uma vez que não sabe muito bem quem são as personagens do romance e nem mesmo sabe muito sobre si mesma. O que move a narradora Maria Clara é o problema do conhecimento, mas a narrativa que constrói e que se mostra em construção dá-se conta de que o conhecimento que ela deveria proporcionar não se completa. De início, temos a impressão de acompanhar Maria Clara numa investigação sobre a sua própria família (em especial sobre o seu pai), mas, em seguida, percebemos que o que ela parece estar descobrindo pode estar sendo criado, inventado por ela. Trata-se de um narrador que afirma e que nega ao mesmo tempo aquilo que conta. Contudo, não escamoteia a dúvida, mas a explicita por meio da representação da narrativa em processo, da escrita sendo feita, apagada e refeita. É nesse sentido queeste romance pode ser considerado o mais autobiográfico, segundo o próprio Lobo Antunes, pois é nele que o autor se representa em seu processo de criação:

É um livro muito autobiográfico. Talvez o mais autobiográfico. Eé também um romance sobre romance. Era um desafio muito grande, é como dar carne, sangue, espessura, a personagens que depois vou destruir dizendo isto não éverdade, existem, mas de outra maneira ${ }^{36}$.

[36] Blanco, op. cit., pp.129-130.

Não entres tão depressa nessa noite escura é o momento da obra de António Lobo Antunes em que sua narrativa se reconhece quando, ao 
Recebido para publicação

em 12 de fevereiro de 2009

\section{NOVOS ESTUDOS}

CEBRAP

83 , março 2009

pp. $219-235$ olhar novamente para a categoria do narrador, coloca-se diante da impossibilidade de um retorno como categoria forte, totalizante. A saída que se apresenta, diante desse reconhecimento, parece ser aquela de que já se tinha indício nas obras anteriores, que diz respeito ao fato de a narrativa se assumir como poesia; não apenas como representação do processo criador que se encena, mas como criação de sentidos reservada à leitura. Isso poderia justificar a inclusão provocativa da designação "poema" que se segue ao título desta obra. Curiosamente, Lobo Antunes chama de poema este que entende como um romance sobre romance. Seria esta já uma resposta àquela provocação evocada no início deste artigo em que o autor dizia pretender transformar a arte do romance? Enveredarmos por estes novos caminhos de discussão exige fôlego renovado, éjá aventura que deve ser reservada a uma outra incursão pelas trilhas do Lobo.

LUÍS FERNANDO PRADO TELLES é doutorando em Teoria e História Literária pela Unicamp e professor das Faculdades de Campinas — Facamp. 